Dr MILOŠ TIMOTIJEVIĆ, naučni saradnik

Narodni muzej Čačak

Čačak, Republika Srbija

slapovi@gmail.com

originalan naučni rad

UDK: 336.13:355.48(497.1)"1941/1944"(093.2)

primljeno: 21. maj 2018.

prihvaćeno: 20. mart 2019.

https://doi.org/10.29362/ist20veka.2019.2.tim.137-156

\title{
FINANSIJE JVuO U SRBIJI 1941-1944.
}

APSTRAKT: Problem obezbeđenja dovoljne količine finansijskih sredstava za delovanje JVuO generala Mihailovića značajno je uticao na tok rata $i$ nije imao samo vojne posledice (otpor okupatoru, kvislinzima, sukobi sa partizanima), već se prelamao i preko odnosa sa lokalnim stanovništvom i zapadnim saveznicima, prvenstveno Britancima. Snage generala Mihailovića dobijale su zlato i novac putem padobranskih pošiljki i preko jugoslovenskog poslanstva u Istanbulu. Jedan deo novca prikupljao se u samoj zemlji, a izvesna finansijska sredstva Mihailović je direktno ili indirektno dobio od okupacione vlade Milana Nedića. Kada su Britanci u drugoj polovini 1943. prekinuli pomoć, JVuO se okrenula neformalnom obliku finansiranja, koje se svelo na sistematsko otimanje novca, dragocenosti iz svih finansijskih ustanova u okupiranoj Srbiji.

KLJUČNE REČI: novac, zlato, finansije, general Mihailović, JVuO, partizani, Britanci, Milan Nedić, Nemci, Srbija

Obezbeđenje dovoljnih količina ratnog i sanitetskog materijala, odnosno novca ili zlata da bi se taj materijal kupio, predstavlja jedan od osnovnih uslova za uspešno gerilsko ratovanje na okupiranoj teritoriji bilo gde u svetu. ${ }^{1}$ Taj problem do sada je obrađivan na nivou rekonstrukcije i analize delovanja kvislinga i okupacionih vlasti na području cele Jugoslavije, posebno na teritoriji Srbije. ${ }^{2}$ Finansiranje drugih aktera rata nikada nije detaljno razmatrano u domaćoj istoriografiji. Za delovanje Jugoslovenske vojske u Otadžbini (JVuO) generala Mihailovića ustalio se niz stereotipa vezanih za „ogromnu“ pomoć koju su u zlatu dobijali od Britanaca (sa puno namernih preterivanja), ${ }^{3}$ dok je za partizane problem finansija razmatran u okviru razvoja inten-

\footnotetext{
${ }^{1}$ Vane Ivanović, Drugo zvono I (Beograd: Vreme knjige, 1995), 172-173.

${ }^{2}$ Najpotpuniji pregled u: Миодраг Угричић, Новач у Југославији за време Другог светског рата с нарочитим освртом на методе финансираға окупације (Београд: Југословенски преглед, 2000).

${ }^{3}$ Videti: Dušan Plenča, Međunarodni odnosi Jugoslavije u toku Drugog svetskog rata (Beograd: Institut za istorijske nauke, 1962).
} 
dantske delatnosti, ${ }^{4}$ čime se zamućivala prava priroda novca i njegovog korišćenja u ratnim uslovima.

\section{Finansiranje pokreta otpora pukovnika Mihailovića u leto 1941.}

Jedan od najvećih problema pukovnika Mihailovića po prispeću na Ravnu goru 11. maja 1941. bile su finansije. Narod u početku nije bio raspoložen da aktivno pomaže gerilu, uplašen zbog represalija okupatora i nepoverljiv prema tada još nepoznatim ljudima. Tokom leta 1941. počinje prikupljanje novčanih priloga koji su korišćeni za pomaganje porodica oficira odvedenih u zarobljeništvo i stvaranje organizacije otpora. ${ }^{5}$ Ipak, sve su to bila mala sredstva, koja su neredovno stizala. Istovremeno pukovnik Mihailović je već u junu i julu 1941. počeo da prima informacije, instrukcije i novac od obaveštajnog centra jugoslovenske vlade u Istanbulu, odakle mu je upućeno i 900.000 dinara. Međutim, Mihailović je primio samo 400.000, a ostatak novca je ,ispario“ dok je došao na Ravnu goru. ${ }^{6}$

Dosadašnja saznanja govore da su Britanci 27. avgusta 1941. Mihailoviću iz Istanbula poslali 20.000 funti u zlatu. ${ }^{7}$ Koliko je novca stiglo do Mihailovića, ostaje otvoreno pitanje, jer različiti izveštaji daju protivrečne podatke. U svakom slučaju to je bio manji iznos od sume koja je određena, a potom i upućena u okupiranu Jugoslaviju. ${ }^{8}$ Prema sećanjima Boška Kostića, pukovnik Mihailović je već početkom juna 1941. dobio izvesnu novčanu pomoć od bogataša iz Beograda. ${ }^{9}$ Mnogo veća pomoć usledila je posle rasplamsavanja ustanka. Milan Nedić je u dva navrata (15. i 26. oktobra 1941) slao novac Mihailoviću, ukupno 2,5 miliona dinara. Prethodno su obaveštajci pukovnika Mihailovića od Nedića dobili 200.000 dinara. ${ }^{10}$ Uzimanje novca od Nedića nije bila tajna. Okupaciona štampa javno je obelodanila te događaje 13. novembra 1941, odbacujući Mihailovića jer je sarađivao s komunistima. ${ }^{11}$

${ }^{4}$ Videti: Miloš Crevar i Velimir Ostojić, Intendantska služba u NOR-u (Beograd: Vojnoizdavački zavod, 1973); Obren Blagojević, „Naše finansije u periodu narodnooslobodilačke borbe 1941-1945”, Istorija 20. veka, br. XIII, (1975), 5-169; Mitar Vujović, Ekonomska služba Vrhovnog štaba NOV i POJ 1941-1945 (Beograd: Vojnoizdavački i novinski centar, Intendantska uprava SSNO, 1990).

5 Драган Сотировић и Бранко Јовановић, Србија и Равна гора (Београд: Институт за савремену историју, 2004), 52, 67, 96, 118.

${ }^{6}$ Jovan Marjanović, Draža Mihailović između Britanaca i Nemaca. Knjiga I. Britanski štićenik (Zagreb: Globus; Beograd: Narodna knjiga, Prosveta, 1979), 90.

${ }^{7}$ Хедер Вилијамс, Падобранщи, патриоти и партизани: Управа за спещијалне операчије у Југославији 1941-1945 (Београд: Нолит, 2009), 74.

${ }^{8}$ Mark C. Wheeler, Britain and the War for Yugoslavia, 1940-1943 (New York: Columbia University Press, 1980), 275-276; Simon Trew, Britain, Mihailović and the Chetniks, 1941-42. (London: Macmillan Press, 1998), 218; Јован Ђоновић, Моје везе са Дражом Михаиловићем (Београд: Институт за савремену историју, 2004), 81-82, 85.

${ }^{9}$ Boško Kostić, Za istoriju naših dana: odlomci iz zapisa za vreme okupacije (Lille: Jean Lausier, 1949), 34.

10 J. Marjanović, Draža Mihailović..., 131, 148-149.

11 „Изјава претседника владе г. Милана Недића поводом једног саопштења лондонског радиа“, Ново време, 13. 11. 1941, 1. 


\section{Neuspeli pregovori partizana i Mihailovićevih četnika oko podele novca iz trezora Narodne banke u Užicu 1941.}

Filijala Narodne banke u Užicu imala je oko 55 miliona dinara u svom sefu kada su krajem septembra 1941. partizani preuzeli vlast u gradu. ${ }^{12}$ Pećančevi četnici prvi su ušli u oslobođeno Užice i uzeli oko 1,5 milion dinara iz Narodne banke, da bi kasnije otišli na front prema ustašama u Višegradu. ${ }^{13}$

Prema sačuvanoj dokumentaciji partizani su preuzeli 52.642.233 dinara, da bi od te sume odmah uzeli 6.397 .800 dinara (niko nije potpisao priznanicu za taj novac), tako da je u kasi ostalo „samo“ 46.244 .433 dinara. U pitanju su bile papirne novčanice i srebrni kovani novac (9.391.400 dinara). Partizani su po ulasku u grad preuzeli i neutvrđene iznose novca iz drugih lokalnih banaka i komunalnih ustanova u Užicu i zapadnoj Srbiji. ${ }^{14}$ Nedićeva propaganda govorila je o 50 miliona dinara i ,milionskim sumama“ iz ostalih ustanova u gradu. ${ }^{15}$ Prema podacima koje je imao Stevan Žutić, načelnik finansijske uprave Drinske banovine u Užicu 1941, partizani su iz filijale Narodne banke uzeli 50 miliona dinara. ${ }^{16}$

Prema zvaničnoj istoriografiji koja je nastala za vreme socijalizma, dogovor Tita i Draže u Brajićima od 26. oktobra 1941. predviđao je da partizani četnicima treba da daju 5 miliona dinara iz Užica, koliko su i sami zadržavali, dok je ostatak bio namenjen da se podeli stanovništvu. Zbog početka građanskog rata ovaj dogovor nikada nije realizovan. ${ }^{17}$

Prema sećanju Jakše Đelevića, međutim, partizani su četnicima trebali zapravo da isporuče 20 miliona, od ukupno 79 miliona dinara koje su zaplenili. ${ }^{18}$ Slična svedočenja ostavili su i američki oficiri koji su bili kod partizanskih jedinica, kojima je Tito krajem rata saopštio kako je četnicima nudio 25 miliona dinara, ali da sporazum nije izvršen zbog ,četničke izdaje“. ${ }^{19}$

Mnoga partizanska svedočenja govore kako je u Užicu zaplenjeno 75 miliona dinara. ${ }^{20}$ Prema „zvaničnim“ Titovim sećanjima partizani su u Narodnoj

\footnotetext{
12 Никола Живковић, „Прикупљање злата, сребра и новца у Ужицу и његов транспорт за Никшић 1941. године“, Ужички зборник, бр. 4, (1975), 237.

${ }^{13}$ М. Угричић, н. д., 165-166.

${ }^{14}$ Александар Кале Спасојевић, „Колико је Ужички народноослободилачки одред преузео новца у филијали Српске народне банке у Ужицу септембра 1941. године“, Ужички зборник, бр. 9, (1980), 293-300.

15 Б. М., „У приземљу суда у Ужицу, комунисти су зазидали 60 живих људи“, Обнова, 11. 12. 1941,5 .

16 Vojni arhiv Beograd, Nedićeva arhiva, K-20A, F-4, R 44. Najsrdačnije se zahvaljujem koleginici dr Nataši Milićević koja mi je nesebično ustupila ovaj dokumenat.

${ }^{17}$ Venceslav Glišić, Užička republika (Beograd: Nolit, 1986), 137, 203-204.

18 Jakša V. Đelević, Prvi Dražin ađutant Jakša V. Đelević: doprinos istoriji Ravnogorskog pokreta, priredila Biljana J. Đelević (Vindzor, Kanada: B. J. Đelević, 1993), 86.

${ }^{19}$ Louis Huot, Oružje za Tita (Zagreb: Globus, 1981), 204.

20 Ужичка република; записи и сећања 2, уредник Живота Марковић (Титово Ужице: Народни музеј, 1983), 183.
} 
banci zatekli oko 60 miliona dinara, od toga 12 miliona u srebru. ${ }^{21}$ Sumu od 60 miliona dinara beleži i Rodoljub Čolaković. ${ }^{22}$ Tako je zapamtio i Manojlo Korać, s tim da su partizani pored 60 miliona dinara koje su uzeli u Užicu zaplenili još 20 miliona iz poreskih uprava i državnih nadleštava u zapadnoj Srbiji. ${ }^{23}$

Podaci iz sovjetskih dokumenata govore da je Moskva već 1941. imala informacije da je Tito zadržao ogromne količine novca zaplenjenog u trezoru užičke filijale Narode banke, što je bio jedan od važnih uzroka razlaza i sukoba sa snagama pukovnika Mihailovića. ${ }^{24}$ Milovan Đilas je 12. maja 1944. sovjetskim zvaničnicima u Moskvi saopštio kako su jugoslovenski partizani u Užicu 1941. zaplenili 45 miliona rublji. ${ }^{25}$ Ostaje otvoreno pitanje po kojem kursu je Đilas obračunavao dinare i rublje.

U svakom slučaju pukovnik Mihailović nije imao dovoljno novca za izdržavanje svog pokreta otpora, što je dodatno opterećivalo organizaciju koju je stvarao. Iznosi koje su njegove snage zaplenile u oslobođenim gradovima nisu bili veliki. ${ }^{26}$

\section{Britanska finansijska pomoć 1941-1942.}

Prvu britansko-jugoslovensku misiju koja je stigla kod pukovnika Mihailovića predvodio je kapetan Hadson. Zna se da je on za svoje potrebe poneo velike količine papirnog i zlatnog novca, ali ne i tačan iznos te sume. Međutim, te pare nisu bile namenjene pukovniku Mihailoviću, već za aktivnosti britanske misije. ${ }^{27} \mathrm{Na}$ početku ustanka autoritet Mihailovića nije bio veliki, tako da je izbeglička vlada planirala da generalu Novakoviću pošalje svoju misiju predvođenu pukovnikom Baletićem, koji je prema planu trebalo da ponese 300 dolara u zlatu i 3,75 miliona lira. Ovaj plan nikada nije realizovan. ${ }^{28}$

Prva britanska pomoć stigla je avionima u noći 8/9. novembra 1941. godine. Nije puno toga izbačeno iznad Ravne gore, sasvim malo oružja, 4.456 američkih dolara i 181 zlatna funta. ${ }^{29}$ Pravi cilj isporuke bilo je mesto Radovče

${ }^{21}$ M. Crevar i V. Ostojić, $n$. d., 375.

22 Родољуб Чолаковић, Записи из ослободилачког рата II (Сарајево: Свјетлост; Београд: Просвета, Култура, 1966), 20.

${ }^{23}$ Манојло Кораћ, Између Драже и Недића (Крагујевац: Погледи, 2015), 98.

${ }^{24}$ Перо Симић, Дража: смрт дужа од живота (Београд: Службени гласник, 2012), 123.

${ }^{25}$ Москва - Сербия, Белград - Россия : сборник документов и материалов. Том 4, Русскосербские отношения: 1917-1945 г2., приредили Алексеј Тимофејев, Горан Милорадовић, Александр Силкин (Београд: Архив Србије; Москва: Главное архивное управление города Москвы, 2017), 466.

${ }^{26}$ Горан Давидовић и Милош Тимотијевић, Осветьавање истине: документа за политичку и војну историју Чачка, Кьига 1, 1938-1941 (Чачак: Историјски архив, Народни музеј; Краљево: Народни музеј, 2006), 283-283.

27 Уильям Маккензи, Секретная история УСО: Управление спецฺиальных операций в 19401945 г2. (Москва: АЦТ, Транзиткнига, 2004), 162.

28 Milan Terzić, „Još nešto o misijama Stanislava Rapoteca u Jugoslaviji 1941-1942”, Jugoslovenski istorijski časopis, XXXIV, br. 1-2, (2001), 119.

29 Jovan Marjanović, Ustanak i narodno-oslobodilački pokret u Srbiji 1941 (Beograd: Institut društvenih nauka, 1963), 357. 
kod Podgorice u Crnoj Gori, ali je zbog izostanka radio-veze sa ljudima na tom terenu ceo tovar isporučen u zapadnoj Srbiji. ${ }^{30}$ Prema prvobitnom planu od 31. oktobra 1941. u Radovče je trebalo da se isporuči čak 10.000 funti u zlatu, ali to nikada nije realizovano. ${ }^{31}$

Kada je početkom novembra 1941. izbio građanski rat između partizana i četnika, kapetan Hadson je svojoj komandi preporučio da se obustavi svaka pomoć pukovniku Mihailoviću. ${ }^{32}$ Britanci su ipak odlučili da podrže Mihailovića, koji je trebalo da objedini ceo pokret otpora, ali u tom trenutku (krajem 1941) nisu imali dovoljno aviona za planirane misije dopremanja pomoći. ${ }^{33} \mathrm{U}$ svakom slučaju Britanci su bili zainteresovani za održavanje pobune, smatrajući da će četničke i partizanske jedinice vezati dosta italijanskih i nemačkih divizija. Već 11. decembra 1941. pokrenuta je i ideja da se pobunjenicima dostavlja zlato, kako bi na taj način kupovali oružje. ${ }^{34}$

Britanska vlada je 27. decembra 1941. jugoslovenskim vojnim predstavnicima stavila na raspolaganje velika novčana i potrošna sredstva, koja su na Malti pripremljena za slanje u zemlju (6 radio-stanica, 100 tona raznog ratnog materijala, 75.000 dolara i 100.000 engleskih funti u zlatu). ${ }^{35}$ Toliko je bilo određeno, ali ratne prilike nikada ne dozvoljavaju da se unapred pripremljeni planovi do kraja realizuju.

Prema izveštaju Entoni Idna od 15. maja 1942. britanska vlada imala je šest operacija sa 13 vazduhoplovnih ekspedicija u periodu od 30. marta do 24 . aprila 1942, kada su bacali zlato, oružje, municiju i letke. Zbog lošeg vremena pet ekspedicija je moralo da se vrati u bazu bez obavljenog posla. Pošto je general Mihailović 28. aprila izvestio da se zbog potera Nemaca mora povući na sigurniju lokaciju, pomoć je prekinuta. Kada je ponovo uspostavljen kontakt poslate su dve ekspedicije, ali nisu bacile materijal jer im nisu dati znaci gde treba to da urade. ${ }^{36}$ Prema britanskom izveštaju od 12. juna 1942. generalu Mihailoviću i njegovim borcima je od novembra 1941. pa do aprila 1942. upućeno 9.556 američkih dolara, 4.755 .000 italijanskih lira i 14.931 britanska funta. ${ }^{37}$

Britanska pomoć bila je neredovna i oskudna, ali i tako minimalne količine materijala predstavljale su potencijalnu pretnju za okupacioni aparat u Ju-

30 S. Trew, op. cit., 237.

31 Борислав Тодоровић, Последюи рапорт (Крагујевац: Погледи, 2002), 222.

32 F. W. Deakin, „Britanija i Jugoslavija (1939-1945)”, Jugoslovenski istorijski časopis, br. 2, (1963), 47-48.

33 Elisabeth Barker, ,Some factors in British Decision-making over Yugoslavia 1941-4”, in: British policy towards wartime resistance in Yugoslavia and Greece, ed. Phyllis Auty, Richard Clogg (London: Macmillan Press, 1975), 30-33.

34 S. Trew, op. cit., 74, 94, 234-235, 246.

${ }^{35}$ Dušan Plenča, „Međunarodni položaj ustanka u Jugoslaviji“, u: Ustanak u Jugoslaviji 1941. godine i Evropa, urednik Vasa Čubrilović (Beograd: SANU, 1973), 172; Nikola Milovanović, Kontrarevolucionarni pokret Draže Mihailovića. Knj. 1, Izdaja (Beograd: Slovo ljubve, 1983), 242.

${ }^{36}$ Milan Terzić, „Jugoslovenska kraljevska vlada i ubacivanje propagandnog materijala u zemlju 1941-1943", Tokovi istorije, br. 4, (2006), 75.

${ }^{37}$ Коста Николић, „Предговор приређивача“, у: Јован Ђоновић, Моје везе са Дражсм Михаиловићем, приредио Коста Николић (Београд: Институт за савремену историју, 2004), 49-50. 
goslaviji i Srbiji. Pronosile su se glasine o velikim količinama oružja i odeće, posebno o zlatnom novcu koji je dospevao i do Nedićevih službenika u Srbiji. ${ }^{38}$

Zbirni britanski izveštaj o pomoći u periodu od 1. juna do 5. oktobra 1942. govori da je JVuO poslato 32.300.000 italijanskih lira, 8.800 dolara, 25.000 malih zlatnika i 7.500 zlatnih ,napoleona““39 Prema podacima koji su korišćeni za vreme socijalizma, Britanci su u ovom periodu Mihailoviću dostavili 25.000 zlatnih funti, 500 ,napoleona“, 8.500 dolara u papiru i 32 miliona lira. ${ }^{40}$ Iste podatke objavila je i srpska emigracija. ${ }^{41}$ Britanci su JVuO slali čitave sanduke lira, ali ne monetu koja se koristila u Italiji, već okupacioni novac za Afriku. ${ }^{42} \mathrm{U}$ pitanju su bile italijanske lire za istočnu Afriku, koje su Britanci zaplenili u Etiopiji. ${ }^{43}$ C̆ak je i na sanducima sa lirama, koji su bacani iz aviona, bio natpis „Etiopija“". 44

Tokom čitave 1942. godine Britanci su imali na raspolaganju samo četiri aviona „liberatora“ za sve svoje balkanske operacije. Nedostatak preciznih informacija o situaciji na terenu uslovio je da nekoliko transporta za JVuO nije ni stiglo do cilja. Zapravo, Britanci uopšte nisu imali predstavu o tome da li je čak i najskromnija količina materijala zaista došla u Mihailovićeve ruke. ${ }^{45}$ Pošiljke su bacane noću, pa je često dolazilo do nesporazuma i isporuka na mesta koja nisu ni bila označena, kao u slučaju paketa sa 5.000 dukata koji su krajem aprila 1942. pali na područje muslimanskih sela u okolini Sjenice. ${ }^{46}$ Najveći deo vojnog materijala bio je uništen, a novac razgrabljen. Vojnici JVuO našli su samo 140 ,napoleona““. 47 Prema izveštaju generala Mihailovića zlatnike je razgrabila grupa ljudi oko Hasana Zvizdića, nekadašnjeg narodnog poslanika, koje su potom jednim delom predali i Italijanima. ${ }^{48}$

\footnotetext{
${ }^{38}$ Međuopštinski arhiv Čačak (MIAČ), Fond prepisa iz Vojnog arhiva, K-1, F-II, reg. br. 41.

39 J. Marjanović, Draža Mihailović..., 264-265, 304; Б. Тодоровић, н. д., 263; К. Николић, „Предговор приређивача“, 49-50.

${ }^{40}$ D. Plenča, Međunarodni odnosi..., 133.

41 Душан Ј. Ђоновић, „Документа - помоћ која је послата ђенералу Михаиловићу од стране Велике Британије“, Гласник српског историско-културног друштва „Његош“, бр. 4, (1959), 92.

42 Милослав Самарџић, Разговори са равногориима 3 (Крагујевац: Погледи, 2013), 22.

${ }^{43}$ Michael McConville, A small war in the Balkans: British military involvement in wartime Yugoslavia, 1941-1945 (Uckfield: Naval \& Military Press, 2007), 52.

44 Илија М. Павловић, Југославија у Другом светском рату према ратним документима (Мелбурн: И. Ј. Павловић, 1985), 280.

${ }^{45}$ Х. Вилијамс, $н . д ., 110$.

${ }^{46}$ Документа са суђења Равногорском покрету: 10. јуни - 15. јули 1946. године: национални и међународни прописи, интегрални стенограм, пресуде, молбе за помиловање, скраћенице, шифре, псеудоними, списак коришћених докумената, најзначајнија документа, библиографија и регистар. Књига 1, приредио Момчило Зечевић (Београд: СУБНОР Југославије, 2001), 527.

${ }^{47}$ Zbornik dokumenata i podataka o narodnooslobodilačkom ratu naroda Jugoslavije. Tom XIV, knj. 1, Dokumenti četničkog pokreta Draže Mihailovića 1941-1942 (Beograd: Vojnoistorijski institut, 1981), 353.

${ }^{48}$ Документа са суђења... Кюига 3, 2212.
} 


\section{Finansijska pomoć jugoslovenske vlade u izbeglištvu tokom 1942. godine}

Mihailovića je pomagala i jugoslovenska vlada. Početkom novembra 1941. poslali su mu 2.500 „napoleona“, 50.000 dolara i 500.000 dinara, a u januaru 1942. (preko Rapoteca) 92 „napoleona“ i 3,5 miliona lira. ${ }^{49}$ Vlada Kraljevine Jugoslavije odobrila je 20. maja 1942. da se JVuO preko „engleskih veza" uputi pomoć u visini od 40.000 funti, pri čemu se jedna funta kupovala za 600 dinara. $^{50}$

Vlada je preko nekoliko tajnih kanala slala finansijsku pomoć generalu Mihailoviću. Iz Švajcarske su 27. aprila 1942. poslali 30.000 švajcarskih franaka (preko poslanstva u Vatikanu), a početkom maja 1942. preko Istanbula poslato je u više navrata ukupno 12.150 dolara, ali je deo te sume trošen i u samoj Turskoj. Istog meseca Mihailoviću je trebalo da se pošalje i 40.000 funti, odnosno 24 miliona dinara po kursu od 600 dinara za jednu funtu. Izveštaji govore da je JVuO poslato samo 22 miliona, pri čemu nije bilo jasno da li je Mihailović novac uopšte i dobio. ${ }^{51}$ Prema procenama jugoslovenskog poslanstva u Turskoj, Mihailović je do sredine leta 1942. primio svega $10 \%$ poslatih finansijskih sredstava. ${ }^{52}$ Postojao je i plan da se iskoriste veze beogradskih poslovnih ljudi sa nemačkim industrijalcima (što im je omogućavalo putovanja), kako bi JVuO preko računa iz Švajcarske dobijala novac od vlade u Londonu. U jesen 1942. razmišljalo se o sumi od 10 do 20 miliona dinara koja bi se na taj način poslala pokretu generala Mihailovića. ${ }^{53}$

Koliko je tačno JVuO dobila novca od jeseni 1942. pa do proleća 1943. nije u potpunosti poznato. Vlada u Londonu odlučila je 28. januara 1943. da Mihailoviću iz budžeta obezbedi 92.000 funti. Prethodno je preko Istanbula poslato 2,5 miliona dinara, koji su promenjeni u 41.666 turskih lira. Da li su te pare kasnije uopšte upućene u zemlju i koliko je novca zaista stiglo do Jugoslavije, veliko je pitanje. Vlada nekim ljudima nije priznala navodne „pozajmice“ generalu Mihailoviću u visini 1,5 miliona italijanskih lira tokom 1942. i 1943. godine. ${ }^{54}$

\footnotetext{
49 Душан Ј. Ђоновић, „Документа - помоћ у новцу Краљевске југословенске владе ђенералу Михаиловићу“, Гласник српског историско-културног друштва „Његош“, бр. 6, (1960), 98-99.

50 Записници са седница Министарског савета Краљевине Југославије: 1941-1945, приредили Комнен Пијевац и Душан Јончић (Београд: Службени лист СЦГ, Архив Србије и Црне Горе, 2004), 98.

51 Д. Ђоновић, „Документа - помоћ у новцу Краљевске југословенске владе ђенералу Михаиловићу“, 100-104.

52 Jugoslavenske vlade u izbjeglištvu: 1941-1943: dokumenti, priredio Bogdan Krizman (Beograd: Arhiv Jugoslavije; Zagreb: Globus, 1981), 326.

53 Војин Андрић, Ратни дневник: септембар - новембар 1944 (Крагујевац: Погледи, 2015), 70 .

54 Записници са седница..., 264, 448.
} 


\section{Pomoć JVuO koja je stigla iz inostranstva tokom 1943. godine}

Prema dosadašnjim saznanjima $\mathrm{JVuO}$ je od februara do kraja marta 1943. dobila 1.000 britanskih zlatnika, 20.000 dolara i 31.050 .000 lira. Od maja do oktobra 1943. dobili su još 5.770 zlatnih funti, 2.015 „napoleona“, 81.600 dolara, 7.946.000 lira, 16.027.000 leva, 1.065.000 leja i 13.600.000 dinara. Novac koji je upućen nije u punom iznosu stigao do JVuO. Zabeležen je gubitak 1.290 zlatnih funti, 500 „napoleona“, 70.900 lira, 22.737 dolara, 4.487 .000 leva, 51.000 leja i 535.750 dinara. Generalu Mihailoviću je 24. septembra 1943. poslato i dva miliona lira, a do kraja godine još 17 miliona dinara preko Istanbula. ${ }^{55}$ Postoje razni izveštaji koliko je zlata i novca dobio general Mihailović. U svakom slučaju od jeseni 1943. i takva pomoć prestaje.

Mihailović je dosta novca dobijao putem jugoslovenskog obaveštajnog centra u Istanbulu. Za prenos „lozinki“ neophodnih za predaju i isplatu novca angažovan je i Boško Kostić, koji se seća da je na taj način krajem 1943. isplaćeno oko 30 miliona dinara. Značajan deo para dat je porodicama oficira koji su se nalazili izvan zemlje. ${ }^{56}$

Količine novca koje je JVuO dobila do tada nisu bile velike. Prema podacima tužilaštva Titovog režima na sudskom procesu generalu Mihailoviću (1946), jugoslovenska vlada u emigraciji je posle 1. juna 1942. isporučila JVuO oko 25.000 zlatnih funti, 500 napoleondora i 32 miliona lira ${ }^{57}$ Sam general Mihailović je na svom suđenju izjavio kako je u proleće i leto 1942, kao i u kasnijem periodu, dok je pomoć uopšte stizala, ukupno dobio oko 20.000 zlatnih funti, zatim 9.000 zlatnih funti koje je direktno poslao kralj, kao i britansku pomoć od 30 miliona italijanskih lira. U svakom slučaju sva primanja i davanja general Mihailović je beležio u posebne knjige, koje su zaplenjene prilikom njegovog hapšenja. ${ }^{58}$

Prema za sada poznatim podacima general Mihailović i njegove snage su iz fondova britanske tajne službe tokom rata dobili ukupno 45.410 britanskih funti u zlatu, 5.000 američkih dolara u zlatu, 2.015 napoleondora (zlatnika), 99.420 dolara u novčanicama, 75.980.000 italijanskih lira, 11.540 .000 bugarskih leva, 1.014.000 rumunskih leja i 13.064.000 Nedićevih okupacionih dinara. Svi navedeni iznosi izračunati su posle odbijanja gubitaka finansijskih sredstava („nestali“ novac i zlato). Osim britanskih pošiljki, Mihailović je na razne načine dobijao i pomoć jugoslovenske izbegličke vlade. Prema zvaničnim podacima $\mathrm{JVuO}$ je iz tih fondova primila 2.500 napoleondora, oko 50.000 funti sterlinga, 52.000 američkih dolara, 10 do 15 miliona rumunskih leja i nekoliko miliona

\footnotetext{
55 Д. Ђоновић, „Документа - помоћ која је послата ђенералу Михаиловићу од стране Велике Британије“, 92-94; D. Plenča, Međunarodni odnosi..., 193-194.

${ }^{56}$ B. Kostić, $n$. d., 122.

57 Документа са суђења..., Књига 2, 1699.

58 Документа са суђења..., Књига 1, 270-271; Nikola Milovanović, Kontrarevolucionarni pokret Draže Mihailovića. Knj. 2, Poraz (Beograd: Slovo ljubve, 1983), 246.
} 
Nedićevih dinara. Britanci su sa izbegličkom vladom preko svojih obaveštajnih centara u Kairu i Istanbulu planirali da se u okupiranoj Srbiji, pre svega u Beogradu, formira fond od oko 100 miliona Nedićevih dinara koje bi prikupili bogati simpatizeri JVuO (industrijalci i trgovci). Oni bi zauzvrat $\mathrm{u}$ inostranstvu dobili kredit za svoju akciju. Ovaj plan nikada nije profunkcionisao. ${ }^{59}$ Prema Mladenu Žujoviću zapadni saveznici nisu pristali da garantuju za zajmove koje bi Mihailović uzimao u Srbiji. Nikada na svojim radio-stanicama nisu pustili poruku koja je bila ugovorena kao pozitivan znak zajmodavcima. ${ }^{60}$

Finansijskim komitetom JVuO u Beogradu rukovodio je inženjer Borivoje Radenković, koji je po planu trebalo da bude i privremeni guverner Narodne banke u trenutku oslobođenja zemlje. Na samom početku osnivanja ravnogorske organizacije industrijalci Vlada Vukojičić i Bata Brunclik davali su velike priloge JVuO i omogućili širenje mreže pomoći među bogatijim stanovnicima Beograda. ${ }^{61}$ Najviše priloga davali su ,sitniji poslovni ljudi“, dok su bogataši nastojali da budu lojalni i okupacionoj vladi Milana Nedića. Veliki industrijalci često su direktno kontaktirali generala Mihailovića i pomagali JVuO u materijalu koji je potreban vojsci. ${ }^{62}$ Kada su u pitanju finansije među komandantima JVuO izdvojio se kapetan Zvonko Vučković, komandant Prvog ravnogorskog korpusa i samog jezgra organizacije JVuO oko Ravne gore, koji je obavljao većinu uplata i isplata novca i zlata, kao i niz obaveštajnih poslova. ${ }^{63}$

Pred kraj rata ravnogorci su problem nedostatka finansijskih sredstava pokušavali da reše raspisivanjem ,prinudnih“ zajmova na nivou okruga, koji su uzimani od ,privatnih lica“. Na taj način okružne i sreske komande JVuO delovale su i kao finansijski odbori. Većina seljaka davala je male sume od 50 do 500 dinara, dok su bogatiji zemljoradnici prilagali između 10.000-15.000 dinara. Ravnogorci su za primljeni novac izdavali priznanice. JVuO je ponekad rekvirirala novac i od kockara ili Srpske državne straže. Pare su upotrebljavane za nabavku hrane, lekova, pomoć sirotinji, udovicama palih boraca JVuO i plaćanje kurira. ${ }^{64}$

Međutim, nije sve bilo tako idealno, jer su pojedini komandanti JVuO u Srbiji nasilno uzimali „dobrovoljne priloge“ u visini od 200.000 dinara, kao „pomoć narodu“. Slali su ucenjivačka pisma, pa su pojedini ljudi prodavali kuće

59 Jozo Tomasevich, Četnici u Drugom svjetskom ratu 1941-1945 (Zagreb: Sveučilišna naklada, Liber, 1979), 271.

${ }^{60}$ Младен Ј. Жујовић, Ратни дневник 3. Југославија у II светском рату (мај 1944 - мај 1946), приредила Теодора Жујовић (Врњачка Бања: Интерклима-графика, 2004), 330.

${ }^{61}$ Д. Сотировић и Б. Јовановић, н. д., 310, 314, 326-328.

${ }^{62}$ Милослав Самарџић, Генерал Дража Михаиловић и општа историја четничког покрета. Кюb. 4 (Крагујевац: Погледи, 2007), 111-112.

${ }^{63}$ Nikola Milovanović, Kontrarevolucionarni pokret Draže Mihailovića. Knj. 3, Rasulo (Beograd: Slovo ljubve, 1983), 68-71; Милош Тимотијевић, Звонко Вучковић: ратна биографија (1941-1944): расправа о проблемима прошлости и садашњости (Београд: Службени гласник, 2015), 430.

${ }^{64}$ Бојан Б. Димитријевић, Ваљевски равногорци. Југословенска војска у Отацбини у ваљевском крају 1941-1945 (Београд: Српска реч, 1998), 165, 175, 233. 
kako bi udovoljili samozvanim zaštitnicima nacionalnih interesa. ${ }^{65}$ Mihailović je 18. decembra 1943. upozorio svoje komandante da se zaustavi rad ,probisveta“. 66 Takvih ,gangstera“ bilo je širom Srbije u prvoj polovini 1944. godine. Često su to bili „,beogradski mangupi““ koji su koristili „objave“ ravnogorskih komandanata kako bi na jednostavan način od ljudi otimali novac i dragocenosti, pri čemu nisu štedeli ni izbeglice. ${ }^{67}$

\section{Alternativni vidovi finansiranja JVuO tokom 1944. godine}

Posle prekida britanske pomoći, finansiranje JVuO moralo je da se organizuje neformalnim kanalima. Početkom maja 1944. Mladen Žujović je isposlovao da se generalu Mihailoviću od Ministarskog saveta pošalje 1.000 zlatnika „napoleona“ i 30.000 dolara. Pošto je državna kasa bila prazna (postojeći budžet omogućavao je isplate samo do 1. juna 1944), zlatnici su ,prepolovljeni“" na 500 komada. Pojavili su se i politički problemi. Prilikom isplate novca određenog za JVuO ovlašćeni činovnik odbio je da izvrši naređenje, jer Mihailović nije više bio ministar vojni. Novac je ipak uzet, a Britanci su taj čin okarakterisali kao ,krađu“. 68

Britanci su imali negativan odnos prema bilo kakvim samostalnim aktivnostima Mihailovićevih oficira izvan Jugoslavije. Zato su krajem maja 1944. u Bariju majorima Baćoviću i Lukačeviću oduzeli dokumentaciju i novac koju su nosili iz Kaira za Jugoslaviju. Prema Vasiliju Trbiću tu je bilo raznih dragocenosti i papirnih banknota u visini 100.000 američkih dolara. ${ }^{69}$ Pokušaj da se zbog ove zaplene novca odloži evakuacija britanskog brigadnog generala Armstronga iz Pranjana ispod Ravne gore nije uspeo. ${ }^{70}$ Britanci su, uz to, pokušali da putem korupcije pridobiju oficire $\mathrm{JVuO}$. Takav pokušaj propao je u kontaktu sa majorom Keserovićem. ${ }^{71}$ Sličnom taktikom, međutim, uspeli su da pridobiju majora Đurića na jugu Srbije, koga su jedno vreme spremali kao ozbiljnog kandidata da zameni generala Mihailovića u skladu sa strategijom „dvorske revolucije“ ${ }^{72}$

65 Драгољуб М. Михаиловић, Рат и мир ђенерала: изабрани ратни списи. Друга књига, приредили Милан Весовић, Коста Николић и Бојан Димитријевић (Београд: Српска реч, 1998), 113, 233.

${ }^{66}$ М. Самарџић, Генерал Дража Михаиловић..., Къь. 4, 124-125.

${ }^{67}$ Извештаји и наредбе ДМ о организаиије Збор за Округ зајечарски: документа 3, 1943 1944, приредио Ненад Пантић (Неготин: Историјски архив, 2008), 80, 127.

${ }^{68}$ Младен Ј. Жујовић, Зборник докумената из заоставштине Младена Ј. Жујовића, приредила Теодора Жујовић (Врњачка Бања: Интерклима-графика, 2004), 14-15, 17-18, 28, 31-32.

${ }^{69}$ Zbornik dokumenata i podataka o narodnooslobodilačkom ratu naroda Jugoslavije. Tom XIV, Knj. 3, Dokumenti četničkog pokreta Draže Mihailovića, septembar 1943-jul 1944 (Beograd: Vojnoistorijski institut, 1983), 724; Василије Трбић, Мемоари. Кю. 2, Казивања и доживљаји војводе велешког: (1912-1918, 1941-1946) (Београд: Култура, 1996), 262.

70 Dejvid Martin, Mreža dezinformacija: Čerčilova jugoslovenska greška (Beograd: Prosveta, 1991), 245.

${ }^{71}$ Ј. Ђоновић, н. д., 217.

72 Коста Николић, Историја равногорског покрета 3 (Београд: Српска реч, 1999), 378-379, 388-389. 
Posle 1942. Britanci su napravili „veliku igru“ oko optužbe za kolaboraciju JVuO sa Italijanima. Na delu je bila „dvoličnost Britanaca“, koji su JVuO do 1943. davali zlato sa izričitom namenom da njime kupuje oružje od Italijana u vreme kada saveznici nisu bili u mogućnosti da pomažu gerilu u Jugoslaviji. To je bila uobičajena praksa, primenjivana i za nabavku oružja za Poljsku otadžbinsku armiju, što su savetovali i Titovim partizanima (6. decembra 1943), jer je britanska obaveštajna služba posedovala zlato u „neograničenim“ " količinama. $^{73}$

Tokom celog rata organizacija $\mathrm{JVuO}$ imala je ozbiljne probleme $\mathrm{u}$ pogledu snabdevanja i izdržavanja svojih snaga, a zatim i brige o stanovništvu na terenu koji su kontrolisali. Prikupljanje „dobrovoljne“ pomoći nije bilo popularno u narodu, stvaralo je otpor prema organizaciji koja sprovodi takve akcije, uz neizbežnu pojavu mnogih zloupotreba. ${ }^{74}$ Sve je to uslovilo potrebu za „neformalnim" načinima finansiranja pokreta generala Mihailovića. Procenjuje se da su snage JVuO tokom 1944. godine ,preuzele“ 1,23 milijardi dinara iz ustanova koje je kontrolisala vlada Milana Nedića. Oduzimanje novca organizovano je upadima u vozove (19,5 miliona), a potom i obijanjem raznih trezora širom zemlje (49,9 miliona). Pare su uzete i iz kamiona Narodne banke koji je prevozio pošiljku iz Zavoda za izradu novčanica (665 miliona), i iz samog trezora Narodne banke u Beogradu (500 miliona).$^{75}$ To su bile velike sume (iako je postojala i velika inflacija), jer je Nedićeva administracija celokupan budžet za 1944. planirala u visini 8,01 milijardi dinara. ${ }^{76}$

Istovremeno, vlada Milana Nedića povremeno je tajno pomagala $\mathrm{JVuO}$, uključujući i slanje novca. Ponekad se finansiranje JVuO tokom 1942. „pokriva10 “ objašnjenjima da se na terenu odigrala obična pljačka. ${ }^{77}$ Nedićeva vlada je $i$ kasnije pomagala organizaciju JVuO. Tako je jula 1944. bez znanja Nemaca poslala 20 miliona dinara $\mathrm{JVuO}$ u Bosni i Hercegovini. Novac je primio Petar Baćović. $^{78}$

Tokom 1944. godine, posebno u zapadnoj Srbiji, pljačkanje vozova, ambulantnih kola, železničkih stanica, pošta i banaka, postali su uobičajeni načini prikupljanja novca za JVuO. U tim akcijama izdvajala se aktivnost kapetana Predraga Rakovića, komandanta Drugog ravnogorskog korpusa. ${ }^{79} \mathrm{Ne}-$ dićeva policija je znala da su sve pljačke u zapadnoj Srbiji izvršila ista lica, ali se za njima bezuspešno tragalo. ${ }^{80}$ Zbog sve učestalijih napada na banke i pošte

\footnotetext{
${ }^{73}$ Х. Вилијамс, н. д., 262.

${ }^{74}$ Коста Николић, Страх и нада у Србији 1941-1944: свакодневни живот под окупащијом (Београд: Завод за уџбенике и наставна средства, 2002), 178-179.

${ }^{75}$ М. Угричић, н. д., 146-149.

${ }^{76}$ Karl-Heinz Schlarp, Wirtschaft und Besatzung in Serbien: 1941-1944: ein Beitrag zur nationalsozialistischen Wirtschaftspolitik in Südosteuropa (Stuttgart: Steiner-Verlag, 1986), 400.

77 Станислав Краков, Генерал Милан Недић. Къ. 2. Препуна чаша чемера (Минхен: Искра, 1968), 470-471.

${ }^{78}$ Исто, 161-162.

${ }^{79}$ Narodni muzej Čačak (NMČ), Zbirka Pretstojništva gradske policije Čačak (PGP), br. 176/44 (7650/4).

${ }^{80}$ NMČ, PGP, br. $232 / 44$
} 
Nedićeva vlast je svim okružnim načelnicima naredila da budu blagovremeno obavešteni o tome kada dolazi novac u njihovo područje. Načelnici u Čačku i Užicu nisu posebno kažnjeni jer nisu vodili računa o „državnoj imovini“", osim što im je upućena „kritika“. Istovremeno Nedić je posle ovih događaja sve svoje načelnike unapred smatrao odgovornim za nove pljačke novca u zoni njihove nadležnosti. ${ }^{81}$

Slične akcije JVuO trebalo je da se organizuju u Beogradu. Prvi Mihailovićev pokušaj da dobije novac iz beogradske Narodne banke vezuje se za kraj 1943, kad je jedan njegov specijalni opunomoćenik ,za sebe“ tražio kredit od 50 miliona dinara. Nemci su osujetili ovaj „legalni“ način uzimanja novca, otpustili su većinu činovnika banke, uhapsili ljude JVuO, pritiskajući i samog Nedića u vezi sa ovim slučajem. ${ }^{82}$

Ovaj neuspeh nije obeshrabrio JVuO. Početkom juna 1944. Mihailovićevi beogradski ilegalci uspostavili su novu vezu sa ljudima iz Narodne banke. To im je omogućilo da presretnu kamion koji je transportovao novac iz Državne kovnice za Narodnu banku. Prema njihovom sećanju tada su zaplenili 1,1 milijardu dinara. Manji deo novca zadržali su za svoje potrebe, a najveći deo para poslat je u zapadnu Srbiju, na Ravnu goru. Upad u Narodnu banku izvršili su i u drugoj polovini avgusta 1944. godine. Akcija je izvršena preko dana, veoma drsko, sa unapred pripremljenim kamionom. JVuO je uzela nekoliko stotina miliona dinara i ,ostali materijal“", koji su zajedno sa guvernerom banke odvezli na Ravnu goru. ${ }^{83}$

Američka misija u JVuO izveštavala je početkom septembra 1944. o ovim akcijama, navodeći kako su četnici uzeli 650 miliona dinara iz Narodne banke u Beogradu. ${ }^{84}$ Nedićevi i nemački stražari su razoružani, a novac je sporednim ulicama prevezen do periferije Beograda gde je natovaren na konje. Zarobljeni stražari (bez oružja) i kamioni vraćeni su u Beograd. Pošto je novac na Ravnoj gori primljen i prebrojan, general Mihailović napisao je priznanicu da je uzeo ,zajam“ od Narodne banke. Ugovoreni kurs američkog dolara i dinara iznosio je 1:1500-1800. ${ }^{85} \mathrm{U}$ to vreme (13. avgust 1944) u Beogradu se za kilogram krompira plaćalo 90 , hleba 200 , a masti 1.350 dinara. ${ }^{86}$

Prema sećanjima ravnogoraca oni su tokom leta uzeli oko 1,8 milijardi dinara od Narodne banke u Beogradu, dok zvanični izveštaji ove ustanove govore o 1,23 milijardi dinara. Ovaj drugi iznos pominje se i u ljotićevskoj emi-

\footnotetext{
${ }^{81}$ Извештаји и наредбе.., 201.

${ }^{82}$ Миодраг Д. Пешић, Дража Михаиловић у извештајима америчких и британских обавештајай 1941-1944 (Крагујевац: Погледи, 2003) 167.

${ }^{83}$ Д. Сотировић и Б. Јовановић, н. д., 323, 330-332.

${ }^{84}$ Веселин Ђуретић, Савезници и југословенска ратна драма: између националних и идеолошких изазова. 2 (Београд: Политика, Сремпублик; Ћуприја: Економика, 1992), 438.

${ }^{85}$ Роберт Мекдауел, Стрељање историје: кључна улога Срба у Другом светском рату (Београд: Поета, Рад, 2012), 247.

${ }^{86}$ Свакодневни живот под окупацијом 1941-1944: искуство једног Београђанина [Драгутина Ранковића], приредили Наташа Милићевић и Душан Никодијевић (Београд: Институт за новију историју Србије, 2012), 857-858.
} 
grantskoj literaturi. ${ }^{87}$ Sećanja često sadrže preterivanja i netačnosti. Postoji mogućnost i da su zvanični izveštaji namerno ,nameštani“. Svakako da su u pitanju bile ogromne pare čija sudbina $u$ daljem toku rata nije poznata.

Nasilno uzimanje novca nastavljeno je sve do sastanka Mihailovića i Nedića u Ražani kod Kosjerića (12-13. avgust 1944), kada je dogovoreno da se takvi napadi obustave. Zauzvrat Nedić se obavezao da će JVuO isplatiti 100 miliona dinara, što je ubrzo realizovano. Prema Nedićevom iskazu tokom saslušanja 1946. u pitanju je bio dogovor da se svakog meseca isplaćuje po 100 miliona dinara. ${ }^{88}$ Mihailovićeve jedinice uspele su u ranu jesen 1944. da otmu i jedan nemački transport kod Kruševca, u kome su pronašli pola vagona novčanica srpskih dinara (,hiljadarke“ i ,petstodinarke“), koje su kasnije koristili da plaćaju hranu. ${ }^{89}$

Prema sećanjima preživelih vojnika JVuO, ,znatan deo blagajne Nedićeve Srbije“ tokom povlačenja Mihailovićevih snaga prenet je za Bosnu. Ova svedočanstva govore da su pored novca prenete i, rezerve monopola i stvari od vrednosti“،. Ovim finansijskim sredstvima raspolagao je kapetan Milorad Mitić, koji je poslat u Austriju sa zadatkom da obezbedi smeštaj ranjenika i tifusara. Ubrzo mu se pridružio i pukovnik Aca Nikolić sa odredom oko 100 boraca. Oni, međutim, nisu izvršili povereni zadatak (započeli su privatne poslove), pa je Mihailović imao nameru i da im sudi. ${ }^{90}$

Draža je već 31. januara 1945. dobio izveštaj u kome se kaže da pukovnik Nikolić i kapetan Mitić žive u Beču i kupuju zlato za državni novac. „Bogato opremljene svoje porodice šalju u Italiju“. Vojnici pod njihovom komandom, njih 40, bili su u Gracu. ${ }^{91}$ Pored toga general Nedić je za vreme svog hapšenja u Austriji uspeo da inženjeru Brani Ivanoviću preda 455.000 zlatnih maraka, koje su potom došle u posed generala Ilije Brašića, kasnije do Ranka Brašića, koji su bili u vezi sa JVuO. Sudbina ovog novca ostala je nepoznata, kao i stotina miliona dinara koje je u Bosnu ponela Nedićeva vojska, a zatim predala Dražinoj organizaciji. ${ }^{92}$

Jedinice JVuO nisu sav novac ponele u Bosnu. Dosta para ostalo je u samoj Srbiji. Kada je u jesen 1944. došlo do propasti JVuO, velike količine novca uzeli su partizani. Prilikom zaplene arhive Prve žičke četničke brigade

\footnotetext{
${ }^{87}$ Prema ovim navodima guverner Narodne banke Srbije Mirko Kosić isporučio je sa znanjem Dimitrija Ljotića i Milana Nedića 1,2 milijarde dinara i 130 „bruto kilograma“ zlata i „mnoštvo valute" organizaciji generala Mihailovića. Илија М. Павловић, Милан 5 . Недић и ғегово доба. Къ. 2. Отаџбинско издање (Београд: Нова Искра, 1994), 378.

${ }^{88}$ Milan Borković, Kontrarevolucija u Srbiji: kvislinška uprava: 1941-1944. Knj. 2 (1943-1944) (Beograd: Sloboda, 1979), 331-332; Kosta Nikolić, „Predgovor: Herman Nojbaher o Drugom svetskom ratu u Jugoslaviji“, u: Herman Nojbaher, Specijalni zadatak Balkan (Beograd: Službeni list SCG, 2005), 27.

${ }^{89}$ Милош Младеновић, Лажни идоли и варљиви идеали (Београд: Институт за савремену историју, 2004), 385.

${ }^{90}$ Михаило П. Минић, Расуте кости: (1941-1945) (Детроит: [б. и.], 1965), 110-111.

${ }^{91}$ Zbornik NOR-a, XIV-4, 745.

${ }^{92}$ И. М. Павловић, Милан Ђ. Недић..., 155, 286, 379.
} 
kod Kraljeva pronađeni su i podaci o ljudima kojima je na čuvanje povereno 40 miliona dinara. Partizani su potom efikasno uzeli sav taj novac. ${ }^{93}$

Organizacija $\mathrm{JVuO}$ pokušavala je u leto 1944. da preko Nedića preuzme i zlatne rezerve iz Narodne banke u Beogradu, spreči nemačku pljačku i istovremeno obezbedi finansiranje svojih snaga na kraju rata. Ovaj plan nije uspeo, jer su Nemci odneli sve dragocenosti. ${ }^{94}$

Međutim, pred sam kraj okupacije Beograda, u oktobru 1944. godine, organizacija JVuO uspela je da iz Narodne banke uzme 100,5 kilograma zlata iz samog trezora, kao i još 7,1 kilogram iz kase zamenika guvernera banke. Pored zlata uzeto je 1,03 kilograma platine i neodređena količina novca u stranim valutama, ukupne vrednosti 3.621.645 dinara. Prema procenama Narodne banke ukupna zaplena vredela je 9.743.077 tadašnjih dinara. ${ }^{95}$

Najpoverljiviji ljudi potpukovnika Saše Mihailovića uspeli su uz pomoć simpatizera iz same banke da preuzmu ono što je u tom trenutku bilo dostupno. Zlato koje su uzeli najvećim delom bilo je u polugama, manjim delom u zlatnicima. OZN-a je u proleće 1945. (posle eliminacije Saše Mihailovića) uspela da otkrije lokaciju gde su zlato i platina bili sakriveni i da preuzme sve dragocenosti. ${ }^{96}$

Ovakve i slične akcije uslovile su da posleratna vlast decenijama bude opsednuta mitom o „ogromnim količinama zlata“ kojima je navodno raspolagala JVuO krajem rata. Prema sećanjima Aleksandara Rankovića, potraga za Dražinom arhivom i zlatom nikada nije ni prestala posle 1945. godine. Smatralo se da su „dragocenosti“ ostale skrivene „duboko u zemlji“, ili jarugama, potocima, pećinama. Najviše se tražilo u zapadnoj Srbiji i istočnoj Bosni. Josip Broz Tito je pridavao veliki značaj otkrivanju tog ,podzemnog skladišta“. ${ }^{97}$

Problem obezbeđenja dovoljne količine finansijskih sredstava za delovanje $\mathrm{JVuO}$ generala Mihailovića značajno je uticao na tok rata i nije imao samo vojne posledice (otpor okupatoru, kvislinzima, sukobi sa partizanima), već se prelamao i preko odnosa sa lokalnim stanovništvom i zapadnim saveznicima, prvenstveno Britancima. Partizani su od 1941. aktivno i sistematski uzimali novac iz

\footnotetext{
93 Мирко Ј. Милићевић и Петар Човић, „Развој НОП и НОБ у Краљеву и Срезу жичком од лета 1943. до ослобођења новембра 1944. и конституисање органа нове власти“, у: Борбе с главнином немачке групе армија „Е“ на ибарско-западноморавском правиу у ослобађаюу западне Србије 1944. године, уредник Коча Јончић (Београд: Војноисторијски институт ЈНА; Краљево: Историјски архив, Међуопштински одбор СУБНОР региона Краљево; Чачак: Међуопштински историјски архив, 1990), 445.

${ }^{94}$ М. Угричић, н. д., 140, 142-147.

${ }^{95}$ Исто, 146.

${ }^{96}$ Borivoje Nešković, Operacija gold (Beograd: В. Nešković, 1985), 8-11; Д. Сотировић и Б. Јовановић, н. д., 344-345.

${ }^{97}$ Александар Ранковић, Дневничке забелешке (Београд: Југословенска књига: 2001), 164165.
} 
svih državnih ustanova, kako u oslobođenim mestima, tako i akcijama na terenu širom zemlje, što im je omogućavalo finansiranje mnogih aktivnosti, dok JVuO nije primenjivala tu praksu na početku ustanka. To je bio jedan od važnih ograničavajućih faktora u delovanju organizacije pokreta otpora koji je predvodio pukovnik Mihailović, odnosno njegove vezanosti za saveznike, izbegličku vladu, ali i okupacionu upravu Milana Nedića u Srbiji. Kada su Britanci u drugoj polovini 1943. prekinuli pomoć, JVuO se okrenula neformalnom obliku finansiranja, koje se svelo na sistematsko otimanje novca, dragocenosti iz svih finansijskih ustanova u okupiranoj Srbiji. Kao i u slučaju drugih strateških odluka, i ove akcije JVuO bile su zakasnele i nisu imale uticaj na krajnji ishod rata. 


\section{REFERENCE}

- Andrić, Vojin. Ratni dnevnik: septembar-novembar 1944. Kragujevac: Pogledi, 2015.

- Baković-Radosavljević, Milka. Memoari jedne ravnogorke: komunisti i nacifašisti - oni su isti. Kragujevac: Pogledi; Cačak: Legenda, 2001.

- Barker, Elisabeth. „Some factors in British Decision-making over Yugoslavia 1941-4". In: British policy towards wartime resistance in Yugoslavia and Greece. Ed. Phyllis Auty, Richard Clogg, 22-58. London: Macmillan Press, 1975. DOI: doi.org/10.1007/978-1-349-02232-8_2

- Blagojević, Obren. „Naše finansije u periodu narodnooslobodilačke borbe 1941-1945". Istorija 20. veka, br. 13, (1975), 5-169.

- Borković, Milan. Kontrarevolucija u Srbiji: kvislinška uprava: 1941-1944. Knj. 2, (1943-1944). Beograd: Sloboda, 1979.

- Čolaković, Rodoljub. Zapisi iz oslobodilačkog rata II. Sarajevo: Svjetlost; Beograd: Prosveta, Kultura, 1966.

- Crevar Miloš, i Velimir Ostojić. Intendantska služba u NOR-u. Beograd: Vojnoizdavački zavod, 1973.

- Davidović Goran, i Miloš Timotijević. Osvetljavanje istine: dokumenta za političku i vojnu istoriju Čačka. Knj. 1, 1938-1941. Čačak: Istorijski arhiv, Narodni muzej; Kraljevo: Narodni muzej, 2006.

- Deakin, F. W. „Britanija i Jugoslavija (1939-1945)”. Jugoslovenski istorijski časopis, br. 2, (1963), 43-58.

- Dimitrijević, Bojan B. Valjevski ravnogorci. Jugoslovenska vojska u Otadžbini u valjevskom kraju 1941-1945. Beograd: Srpska reč, 1998.

- Dokumenta sa suđenja Ravnogorskom pokretu: 10. juni-15. juli 1946. godine: nacionalni i međunarodni propisi, integralni stenogram, presude, molbe za pomilovanje, skraćenice, šifre, pseudonimi, spisak korišćenih dokumenata, najznačajnija dokumenta, bibliografija i registar. Knjiga 1. Priredio Momčilo Zečević. Beograd: SUBNOR Jugoslavije, 2001.

- Đelević, Jakša V. Prvi Dražin ađutant Jakša V. Đelević: doprinos istoriji Ravnogorskog pokreta. Priredila Biljana J. Đelević. Vindzor, Kanada: B. J. Đelević, 1993.

- Đonović, Dušan J. „Dokumenta - pomoć koja je poslata đeneralu Mihailoviću od strane Velike Britanije“. Glasnik srpsko istorisko-kulturnog društva „Njegoš“", br. 4, (1959), 90-95.

- Đonović, Dušan J. „Dokumenta - pomoć u novcu Kraljevske jugoslovenske vlade đeneralu Mihailoviću“. Glasnik srpsko istorisko-kulturnog društva „Njegoš“" br. 6 (1960), 98-105.

- Đonović, Jovan. Moje veze sa Dražom Mihailovićem. Beograd: Institut za savremenu istoriju, 2004.

- Đuretić, Veselin. Saveznici i jugoslovenska ratna drama: između nacionalnih $i$ ideoloških izazova. 2. Beograd: Politika, Srempublik; Ćuprija: Ekonomika, 1992. 
- Glišić, Venceslav. Užička republika. Beograd: Nolit, 1986.

- Huot, Louis. Oružje za Tita. Zagreb: Globus, 1981.

- Ivanović, Vane. Drugo zvono I. Beograd: Vreme knjige, 1995.

- Izveštaji i naredbe DM i organizacije Zbor za Okrug zaječarski: dokumenta 3, 1943-1944. Priredio Nenad Pantić. Negotin: Istorijski arhiv, 2008.

- Jugoslavenske vlade u izbjeglištvu: 1941-1943: dokumenti. Priredio Bogdan Krizman. Beograd: Arhiv Jugoslavije; Zagreb: Globus, 1981.

- Korać, Manojlo. Između Draže i Nedića. Kragujevac: Pogledi, 2015.

- Kostić, Boško. Za istoriju naših dana: odlomci iz zapisa za vreme okupacije. Lille: Jean Lausier, 1949.

- Krakov, Stanislav. General Milan Nedić. Knj. 2. Prepuna čaša čemera. Minhen: Iskra, 1968.

- Makdauel, Robert. Streljanje istorije: ključna uloga Srba u Drugom svetskom ratu. Beograd: Poeta, Rad, 2012.

- Makkenzi, Uil'jam. Sekretnaja istorija USO: Upravlenie special'nyh operacij v 1940-1945 gg. Moskva: ACT, Tranzitkniga, 2004.

- Marjanović, Jovan. Draža Mihailović između Britanaca i Nemaca. Knjiga I. Britanski štićenik. Zagreb: Globus; Beograd: Narodna knjiga, Prosveta, 1979.

- Marjanović, Jovan. Ustanak i narodno-oslobodilački pokret u Srbiji 1941. Beograd: Institut društvenih nauka, 1963.

- Martin, Dejvid. Mreža dezinformacija: Čerčilova jugoslovenska greška. Beograd: Prosveta, 1991.

- McConville, Michael. A small war in the Balkans: British military involvement in wartime Yugoslavia, 1941-1945. Uckfield: Naval \& Military Press, 2007.

- Milićević Mirko J., i Petar Čović. „Razvoj NOP i NOB u Kraljevu i Srezu žičkom od leta 1943. do oslobođenja novembra 1944. i konstituisanje organa nove vlasti“. U: Borbe s glavninom nemačke grupe armija „E“ na ibarskozapadnomoravskom pravcu u oslobođenju zapadne Srbije 1944. godine. Urednik Koča Jončić. Beograd: Vojnoistorijski institut JNA; Kraljevo: Istorijski arhiv, Međuopštinski odbor SUBNOR regiona Kraljevo; Čačak: Međuopštinski istorijski arhiv, 1990.

- Milovanović, Nikola. Kontrarevolucionarni pokret Draže Mihailovića. Knj. 1, Izdaja. Beograd: Slovo ljubve, 1983.

- Milovanović, Nikola. Kontrarevolucionarni pokret Draže Mihailovića. Knj. 2, Poraz. Beograd: Slovo ljubve, 1983.

- Milovanović, Nikola. Kontrarevolucionarni pokret Draže Mihailovića. Knj. 3, Rasulo. Beograd: Slovo ljubve, 1983.

- Minić, Mihailo P. Rasute kosti: (1941-1945). Detroit: [b. i.], 1965.

- Mihailović, Dragoljub M. Rat i mir đenerala: izabrani ratni spisi. Druga knjiga. Priredili Milan Vesović, Kosta Nikolić i Bojan Dimitrijević. Beograd: Srpska reč, 1998.

- Mladenović, Miloš. Lažni idoli i varljivi ideali. Beograd: Institut za savremenu istoriju, 2004. 
- Moskva - Serbija, Belgrad - Rossija: sbornik dokumentov i materialov. Tom 4, Russko-serbskie otnoshenija: 1917-1945 gg. Priredili Aleksej Timofejev, Goran Miloradović i Aleksandr Silkin. Beograd: Arhiv Srbije; Moskva: Glavnoe arhivnoe upravlenie goroda Moskvy, 2017.

- Nešković, Borivoje. Operacija gold. Beograd: B. Nešković, 1985.

- Nikolić, Kosta. „Predgovor: Herman Nojbaher o Drugom svetskom ratu u Jugoslaviji“. U: Herman Nojbaher, Specijalni zadatak Balkan. Priredio Nikola Živković, 7-31. Beograd: Službeni list SCG, 2005.

- Nikolić, Kosta. „Predgovor priređivača“. U: Jovan Đonović, Moje veze sa Dražom Mihailovićem. Priredio Kosta Nikolić, 7-75. Beograd: Institut za savremenu istoriju, 2004.

- Nikolić, Kosta. Istorija ravnogorskog pokreta, 3. Beograd: Srpska reč, 1999.

- Nikolić, Kosta. Strah i nada u Srbiji 1941-1944: svakodnevni život pod okupacijom. Beograd: Zavod za udžbenike i nastavna sredstva, 2002.

- Pavlović, Ilija M. Jugoslavija u Drugom svetskom ratu prema ratnim dokumentima. Melburn: I. J. Pavlović, 1985.

- Pavlović, Ilija M. Milan Đ. Nedić i njegovo doba. Knj. 2. Otadžbinsko izdanje. Beograd: Nova Iskra, 1994.

- Pešić, Miodrag D. Draža Mihailović u izveštajima američkih i britanskih obaveštajaca 1941-1944. Kragujevac: Pogledi, 2003.

- Plenča, Dušan. Međunarodni odnosi Jugoslavije u toku Drugog svetskog rata. Beograd: Institut za istorijske nauke, 1962.

- Plenča, Dušan. „Međunarodni položaj ustanka u Jugoslaviji“. U: Ustanak u Jugoslaviji 1941. godine i Evropa. Urednik Vasa Čubrilović, 57-183. Beograd: SANU, 1973.

- Ranković, Aleksandar. Dnevničke zabeleške. Beograd: Jugoslovenska knjiga, 2001.

- Samardžić, Miloslav. General Draža Mihailović i opšta istorija četničkog pokreta. Knj. 4. Kragujevac: Pogledi, 2007.

- Samardžić, Miloslav. Razgovori sa ravnogorcima 3. Kragujevac: Pogledi, 2013.

- Schlarp, Karl-Heinz. Wirtschaft und Besatzung in Serbien: 1941-1944: ein Beitrag zur nationalsozialistischen Wirtschaftspolitik in Südosteuropa. Stuttgart: Steiner-Verlag, 1986.

- Simić, Pero. Draža: smrt duža od života. Beograd: Službeni glasnik, 2012.

- Sotirović Dragan, i Branko Jovanović. Srbija i Ravna gora. Beograd: Institut za savremenu istoriju, 2004.

- Spasojević, Aleksandar Kale. „Koliko je Užički narodnooslobodilački odred preuzeo novca u filijali Srpske narodne banke u Užicu septembra 1941. godine“. Užički zbornik, br. 9, (1980), 293-300.

- Svakodnevni život pod okupacijom 1941-1944: iskustvo jednog Beograđanina [Dragutina Rankovića]. Priredili Nataša Milićević i Dušan Nikodijević. Beograd: Institut za noviju istoriju Srbije, 2012. 
- Terzić, Milan. „Još nešto o misijama Stanislava Rapoteca u Jugoslaviji 19411942". Jugoslovenski istorijski časopis, XXXIV, br. 1-2, (2001), 117-126.

- Terzić, Milan. „Jugoslovenska kraljevska vlada i ubacivanje propagandnog materijala u zemlju 1941-1943.". Tokovi istorije, br. 4, (2006), 72-85.

- Timotijević, Miloš. Zvonko Vučković: ratna biografija (1941-1944): rasprava o problemima prošlosti i sadašnjosti. Beograd: Službeni glasnik, 2015.

- Todorović, Borislav. Poslednji raport. Kragujevac: Pogledi, 2002.

- Tomasevich, Jozo. Četnici u Drugom svjetskom ratu 1941-1945. Zagreb: Sveučilišna naklada, Liber, 1979.

- Trbić, Vasilije. Memoari. Knj. 2. Kazivanja i doživljaji vojvode veleškog: (1912-1918, 1941-1946). Beograd: Kultura, 1996.

- Trew, Simon. Britain, Mihailović and the Chetniks, 1941-42. London: Macmillan Press, 1998. DOI: 10.1057/9780230389762

- Ugričić, Miodrag. Novac u Jugoslaviji za vreme Drugog svetskog rata s naročitim osvrtom na metode finansiranja okupacije. Beograd: Jugoslovenski pregled, 2000.

- Užička republika: zapisi i sećanja, 2. Urednik Života Marković. Titovo Užice: Narodni muzej, 1983.

- Vilijams, Heder. Padobranci, patrioti i partizani: Uprava za specijalne operacije u Jugoslaviji 1941-1945. Beograd: Nolit, 2009.

- Vujović, Mitar. Ekonomska služba Vrhovnog štaba NOV i POJ 1941-1945. Beograd: Vojnoizdavački i novinski centar, Intendantska uprava SSNO, 1990.

- Wheeler, Mark C. Britain and the War for Yugoslavia, 1940-1943. New York: Columbia University Press, 1980.

- Zapisnici sa sednica Ministarskog saveta Kraljevine Jugoslavije: 1941-1945. Priredili Komnen Pijevac i Dušan Jončić. Beograd: Službeni list SCG, Arhiv Srbije i Crne Gore, 2004.

- Zbornik dokumenata i podataka o Narodnooslobodilačkom ratu naroda Jugoslavije. Tom XIV, Knj. 1. Dokumenti četničkog pokreta Draže Mihailovića 1941-1942. Beograd: Vojnoistorijski institut, 1981.

- Zbornik dokumenata i podataka o Narodnooslobodilačkom ratu naroda Jugoslavije. Tom XIV, Knj. 3. Dokumenti četničkog pokreta Draže Mihailovića, septembar 1943 - jul 1944. Beograd: Vojnoistorijski institut, 1983.

- Živković, Nikola. „Prikupljanje zlata, srebra i novca u Užicu i njegov transport za Nikšić 1941. godine“. Užički zbornik, br. 4, (1975), 235-241.

- Žujović, Mladen J. Zbornik dokumenata iz zaostavštine Mladena J. Žujovića. Priredila Teodora Žujović. Vrnjačka Banja: Interklima-grafik, 2004.

- Žujović, Mladen J. Ratni dnevnik 3. Jugoslavija u II svetskom ratu (maj 1944 - maj 1946). Priredila Teodora Žujović. Vrnjačka Banja: Interklima-grafik, 2004. 
MILOŠ TIMOTIJEVIĆ, PhD, Research Associate

National museum Čačak

Čačak, Republic of Serbia

slapovi@gmail.com

\section{FINANCING OF THE YUGOSLAV ARMY IN THE FATHERLAND OF GENERAL MIHAILOVIĆ IN SERBIA (1941-1944)}

\section{Summary}

The problem of providing sufficient financial resources for the operations of the Yugoslav Army in the Fatherland (JVuO) headed by General Mihailović, did not only have military consequences (resistance to occupation, quislings, confrontations with partisans), but also affected the relationship with the local population and Western allies, mainly the British.

The forces of General Mihailović received gold and money through several channels; first from the Yugoslav mission in Istanbul and then directly by air through parachute packages. A part of the money was collected in the country itself and Mihailović also received certain financial resources directly or indirectly from the occupational government of Milan Nedić. The Germans were trying to stop such activities in any possible way, but as of the second half of 1943 the financing of the Yugoslav Army in the Fatherland was blocked by Great Britain within their policy of supporting the partisan movement and their rejection of General Mihailović. This resulted in the Yugoslav Army in the Fatherland resorting to more informal ways of financing, which came down to the systematic theft of money and valuables from all financial institutions in occupied Serbia.

According to existing data, during the war, the forces of General Mihailović received 45,410 golden pounds, 5,000 dollars and 4,500 Napoleon coins from abroad. The total was around 55,000 gold coins, as well as several tens of millions of occupational liras and dinars. This small and insufficient help was not increased significantly by the informal financing during 1944 when, according to the official data of the Nedić Government, they took a total of 1.23 billion dinars from banks, post offices and trains.

KEYWORDS: Money, Gold, Finance, General Mihailović, JVuO, Partisans, British, Milan Nedić, Germans, Serbia 